\title{
EVOLUÇÃo SEDIMENTAR E BATIMÉTRICA DA BAÍA DE ANTONINA - PR LYDIO LUIZRISSETTIODRESKI*
}

\author{
DISSERTAÇÃO DE MESTRADO - Programa de Pós-Graduação em Geologia - UFPR \\ DATA DE DEFESA: 26 jul. 02
}

\begin{abstract}
A manutenção dos canais de navegação que acessam os portos organizados de Paranaguá e Antonina, através das operações de dragagens e despejo de material dragado, constituem uma atividade onerosa para os portos e impactante para o meio ambiente. Este estudo procurou oferecer uma contribuição ao conhecimento da dinâmica sedimentar e batimétrica da Baía de Antonina e porção ocidental da Baía de Paranaguá, correlacionando levantamentos históricos de batimetria e de sedimentos de fundo com os dados mais recentes. O resultado desta comparação evidenciou de modo geral uma tendência ao aumento do diâmetro médio dos sedimentos de fundo em toda a área estudada, passando de silte médio, em 1996, para areia muito fina, em 1995. Do ponto de
\end{abstract}

vista batimétrico, ficou caracterizado intenso assoreamento da Baía de Antonina, principalmente na porção superior e nas margens, onde se constatou progradação das planícies de maré. O volume de sedimento depositado no período entre 1901 e 1979 foi cerca de $60 \times 10^{6} \mathrm{~m}^{3}$, caracterizando uma taxa de sedimentação de aproximadamente 2,6 cm/ano. A influência antrópica exercida através da interligação das bacias de drenagem dos rios Capivari e Cachoeira para a construção de uma usina hidroelétrica, do desmatamento da Serra do Mar na região das cabeceiras dos rios e das atividades de drenagens e despejo de material dragado, parece ter tido uma contribuição significativa na aceleração do processo de colmatação desse setor do Complexo Estuarino de Paranaguá. 